\title{
Kirk-Othmer Chemical Technology and the Environment
}

\author{
Wiley-Interscience, New York, NY, Two-Volume Set, Volume 1: General Aspects, \\ "Green" Technology, Materials from Renewable Resources, and Energy (1319 pp), \\ Volume 2: Pollution, and Pollution Prevention and Control, and Regulatory, Health, \\ and Safety (1224 pp). Hardcover (2573 pp), ISBN 978-0-470-10540-5 2007, USD \$560.00 \\ (hardcover)
}

\author{
John A. Glaser \\ Published online: 19 May 2011 \\ (c) Springer-Verlag (outside the USA) 2011
}

These two volumes of chemical and environmental technology are chapter contributions selected from the 5th edition of the Kirk-Othmer Encyclopedia of Chemical Technology. A total of 73 chapters deal with various established and emerging technologies based in biochemical, chemical, and physical science. The individual chapters range in size from 11 to 69 pages with copious references. Specific and general references are provided with each article. The international cast of 150 authors, experts in their field, offers effective approaches to crucial environmental problems associated with or solved by the application of chemical technology. The articles are targeted to an audience having a general background in science. An index of 150 pages aids the search of information in this massive two-volume reference.

The two volumes are organized into the six subject headings of general aspects, "green" technology, materials from renewable resources, energy, pollution prevention and control, and regulatory health and safety issues. In the general aspects area three articles focus on green chemistry, life cycle assessment, sustainable development, and chemistry. The "green" technology section of 15 articles offer considerable insight and in-depth development into powder coating processes, industrial enzyme applications, fermentation, biotechnology herbicides, hydrothermal processing, ionic liquids, membrane technology, metathesis, microbial transformations, chemical synthesis applications using microwave technology, molecular sieves, photothermographic and thermographic imaging materials, process integration technology,

J. A. Glaser $(\bowtie)$

US Environmental Protection Agency, National Risk

Management Research Laboratory, 26 W King Dr, Cincinnati, OH 45268, USA

e-mail: Glaser.John@EPA.gov supercritical fluids, and water desalination. Materials of the renewable resources section include topics: cellulose, cotton, flax fiber, hydrofluorocarbons, hydroxycarboxylic acids, paper, polyhydroxyalkanoates, polylactides, polysaccharides, pulp, silk, wood, and wool. The seven articles in the energy section are devoted to biomass energy, energy management, fuel cells, hydrogen energy, photovoltaic cells, renewable energy resources, and solar energy materials.

The pollution prevention and control section has 21 articles on the following topics: air pollution, indoor air pollution and control, air pollution control methods, bioremediation, dyes, environmental chemistry, automotive and industrial emission control, environmental impact assessment, groundwater monitoring, toxicity and environmental impact of halogenated hydrocarbons, hazardous waste incinerators, hydrogen peroxide, ozone, recycling, soil chemistry of pesticides, sulfur and hydrogen sulfide recovery, hazardous waste management, waste management, radioactive, solid waste management, wastewater treatment, and water treatment.

The final section concentrates on health and safety regulatory considerations and is composed of 14 topics including: environmental impact, health effects, and treatment methods for arsenic, asbestos, disinfection, flame retardants, hazard analysis and risk assessment, industrial hygiene, lead, maintenance, mercury, regulatory agencies, safety, industrial solvents, toxicology, and transportation.

This reference is an asset to anyone involved with chemical technology and its application in the environment. The depth of coverage for each topic offers a launch point providing the background necessary to develop new research endeavors. These two volumes can readily aid the individual researcher and should be on the shelves of any competent library of information about chemical technology and its role in the environment. 